\title{
PEMBINAAN PEGAWAI NEGERI SIPIL PADA DINAS PENDIDIKAN KABUPATEN PIDIE (Studi Implimentasi Peraturan Pemerintah Nomor 12 Tahun 2002 Tentang Kenaikan Pangkat Pegawai Negeri Sipil)
}

\author{
Halimah \\ Program Studi Ilmu Administrasi Negara \\ Fakultas Ilmu Administrasi Universitas Jabal Ghafur Sigli
}

\begin{abstract}
The existence of government employees was a crucial thing in doing the government assignment and development within government organizations. In this case, the government needed professional, strong, responsible, friendly and impersonal employees through coaching conducted base on job and performance career system. Pidie District Education offices needed some steps in developing education was suitable with the job and performance system for realizing a good government employees. The development done was based on the 34th constitution, 12th subsection and 1st verse in 1999 about constitution amendment of the 8th in 1974 about the employees affair that sound was "the government employees management was encouraged to certify the government assignment and development efficiently". Hence, it needed construction continuously from recruitment process became an employee until she/he became pension. It aims to certify the assignment continuously. The aim of the study was to describe and analyze the construction of the government employees on the Pidie District Education Offices and resistor and support factors in developing the government employees. The method of the study was qualitative research by conducting the prime and secondary data were larger. It covered the legal document issued by the government such as the government employee constitution and the expert opinion. Data collection conducted by doing library and documentation research. Data analysis was performed by descriptive analysis, those were: data reduction, display and conclusion/verification. From the research result could be concluded that the process of advancement of the government employees were to get structural position which were still have weaknesses in arranging constructing system or locating a structural position within government bureaucracy. Consequently, it needed firmness in arranging government employees lifting mechanism in structural position.
\end{abstract}

Key Words: Employees, advancement

\section{Latar Belakang Masalah}

Pegawai Negeri Sipil merupakan unsur aparatur negara yang menjalankan tugas Pemerintahan dan pembangunan dalam upaya mencapai tujuan pembangunan Nasional secara menyeluruh sebagaimana dimaksudkan dalam Pembukaan Undang-Undang Dasar 1945, adalah melindungi segenap Bangsa Indonesia dan seluruh tumpah darah Indonesia serta untuk memajukan kesejahteraan kehidupan bangsa serta ikut melaksanakan ketertiban dunia yang berdasarkan kemerdekaan, perdamai abadi dan keadilan sosial bagi seluruh rakyat Indonesia Kelancaran Pemerintahan dan Pembangunan Nasional sangat tergantung dari kesempurnaan Aparatur Negara. Untuk mencapai tujuan Nasional sebagaimana dimaksudkan diatas maka diperlukan adanya Pegawai Negeri Sipil yang berdedikasi tinggi danpenuh kesetiaan serta ketaatan kepada Pancasila, Undang-Undang
Dasar 1945, Negara dan Pemerintah serta bersatu padu, bermental baik, berwibawa, berdaya guna dan berhasil guna, bersih dan berkualitas tinggi dan sadar terhadap tanggung jawab sebagai unsur Aparatur Negara.

Dalam upaya mewujudkan Pegawai Negeri Sipil tersebut bagi Dinas Pendidikan Kabupaten Pidie perlu melakukan langkahlangkah pembinaan dan pendidikan yang sesuai dengan sistem karier dan sistem prestasi kerja. Pembinaan yang dilakukan didasarkan kapada pasal 12 ayat (1) Undang-Undang Nomor 43 Tahun 1999 tentang perubahan atas UndangUndang Nomor 8 Tahun 1974 tentang pokokpokok kepegawaian yang berbunyi "Manajemen Pegawai Negeri Sipil diarahkan untuk menjamin penyelenggaraan tugas Pemerintahan dan pembangunan secara berdaya guna dan berhasil guna". Dengan dilandasi pada uraian diatas, maka dapat dikatakan bahwa Pegawai Negeri 
Sipil merupakan sesuatu hal yang perlu dibina secara terus menerus dan kontinue, sejak mulai dari rekrutmen, pengangkatan menjadi Pegawai sampai Pegawai yang bersangkutan dipensiunkan, oleh karena itu dengan tujuan untuk menjamin penyelenggaraan tugas dalam bidang Pemerintahan dan pembangunan secara berdaya guna dan berhasil guna dan mampu menjalankan tugas-tugas yang telah dibebankan kepadanya.

Dengan sendirinya diharapkan pula seorang Pegawai Negeri Sipil dapat benar-benar mematuhi semua ketentuan atau Peraturan PerUndang-Undangan yang berlaku serta penuh rasa tanggung jawab terhadap pelaksanaan tugas. Dalam suatu organisasi banyak hal memerlukan pengelolaan yang profesional dan terpisah dari hal-hal lain. Kita mengenal berbagai jenis manajemen dalam organisasi, misalnya manajemen produksi, manajemen pemasaran, manajemen keuangan, manajemen informasi, dan tentunya manajemen Sumber Daya Manusia. Jadi mana yang paling penting dari semua jenis manajemen ini? Jawabannya semua mempunyai derajat kepentingan yang sama dalam hal kontribusi terhadap pencapaian tujuan organisasi. Dengan demikian, paran Manajemen Sumber Daya Manusia adalah sama pentingnya dengan peran manajemenmanajemen lain, yakni mengelola semua sumber daya yang dimiliki organisasi untuk mencapai tujuan organisasi. Hanya saja titik berat peran Manajemen Sumber Daya Manusia adalah pada aspek Sumber Daya Manusia yang dimiliki organisasi. Manajemen Sumber Daya Manusia mempunyai fungsi yang selalu muncul setiap kita membahas Manajemen Sumber Daya Manusia tersebut, yang fungsi-fungsinya sebagaimana dikemukakan oleh Prasettyo (2012: 15) yaitu: 1) Perencanaan Sumber Daya Manusia, 2) Seleksi dan orientasi Sumber Daya Manusia, 3) Pengembangan Sumber Daya Manusia, 4) Manajemen Karier, 5) Penilaian Prestasi Kerja, 6) Kompensasi, dan 7) Pemutusan Hubungan Kerja.

Dalam penelitian ini, peneliti menitik beratkan pada pembinaan Pegawai Negeri Sipil pada Dinas Pendidikan Kabupaten Pidie. Pembinaan mengarah pada suatu hal penting terkait kenaikan pangkat dan promosi jabatan. Kenaikan pangkat Pegawai Negeri Sipil di dasarkan pada Peraturan Pemerintah Republik Indonesia Nomor 12 Tahun 2002 tentang Perubahan Atas Peraturan Pemerintah Nomor 99 Tahun 2000 tentang Kenaikan Pangkat Pegawai
Negeri Sipil. Sebagaimana disebutkan dalam pasal 3 Kenaikan pangkat dilaksanakan berdasarkan sistem kenaikan pangkat reguler dan sistem kenaikan pangkat pilihan. Sistem kenaikan pangkat reguler berdasarkan pasal 6 Peraturan Pemerintah No 12 Tahun 2002 tentang Perubahan Atas Peraturan Pemerintah Nomor 99 Tahun 2000 tentang Kenaikan Pangkat Pegawai Negeri Sipil diberikan kepada Pegawai Negeri Sipil yang: a) Tidak Menduduki Jabatan Struktural atau jabatan fungsional tertentu, b) Melaksanakan tugas belajar dan sebelumnya tidak menduduki jabatan struktural atau fungsional tertentu; dan c) Dipekerjakan atau diperbantukan secara penuh di luar instansi induk dan tidak menduduki jabatan struktural atau jabatan fungsional tertentu.

Selanjutnya syarat-syarat yang harus dipenuhi dalam pasal 9 disebutkan bahwa kenaikan pangkat pilihan diberikan kepada Pegawai Negeri Sipil yang: a) Menduduki Jabatan struktural atau jabatan fungsional tertentu, b) Menduduki jabatan tententu yang pengangkatannya ditetapkan dengan keputusan Presiden, c) Menunjukkan prestasi kerja luar biasa baiknya, d) Menemukan penemuan baru yang bermanfaat bagi negara, e) Diangkat menjadi pejabat negara, f) Memperoleh Surat tanda Tamat Belajar atau Ijazah, g) Melaksanakan tugas belajar dan sebelumnya menduduki jabatan struktural atau jabatan fungsional, h) Telah selesai mengikuti dan lulus tugas belajar, i) Dipekerjakan atau diperbantukan secara penuh di luar instansi induknya yang diangkat dalam jabatan pimpinan atau jabatan fungsional tertentu. Syarat-Syarat lain yang harus dipenuhi agar seorang Pegawai Negeri Sipil dapat diangkat dalam jabatan struktural sesuai dengan pasal 5 Peraturan Pemerintah Republik Indonesia Nomor 13 Tahun 2002 tentang Perubahan Atas Peruran Pemerintah Nomor 100 Tahun 2000 tentang Pengangkatan Pegawai Negeri Sipil dalam jabatan struktural, disebutkan : a) Berstatus Pegawai Negeri Sipil, b) Serendah-rendahnya menduduki pangkat 1 (satu) tingkat dibawah jenjang pangkat yang ditentukan, c) Memiliki kualifikasi dan tingkat pendidikan yang ditentukan, d) Semua unsur penilaian prestasi kerja sekurang-kurangnya bernilai baik dalam 2 (dua) tahun terakhir, e) Memiliki kompetensi jabatan yang diperlukan, dan f) Sehat jasmani dan rohani. Di samping persyaratan tersebut di atas, Pejabat Pembina Kepegawaian Daerah perlu memperhatikan faktor senioritas dalam 
kepangkatan, usia, pendidikan dan pelatihan jabatan dan pengalaman yang dimiliki. Berdasarkan penelitian awal yang telah peneliti lakukan pada Dinas Pendidikan Kabupaten Pidie selama ini kenaikan pangkat terhadap Pegawai Negeri Sipil berjalan lancar.

Menurut pendapat Enceng, dkk (2009: 44) bahwa "Promosi berarti pemindahan seseorang dari satu pekerjaan ke pekerjaan lain atau dari satu jabatan ke jabatan lain secara vertikal ke atas, yakni menerima tanggung jawab lebih besar dari tanggung jawab sebelumnya". Pemberian promosi kepada Pegawai tidak harus diartikan untuk memenuhi kebutuhan atau keinginan Pegawai, tetapi harus dilihat dalam kegiatan organisasi secara keseluruhan. Berdasarkan penelitian awal data kenaikan pangkat reguler Dinas Pendidikan Kabupaten Pidie selama tahun terakhir yakni tahun 2015 ada 3 orang pegawai yang telah diproses kenaikan pangkatnya sesuai dengan prosedur yang berlaku. Di samping itu ada pegawai yang tertunda kenaikan pangkat selama satu priode dikarenakan tidak memenuhi syarat dengan masa tunggu antara 8 sampai dengan 14 tahun

Pada dasarnya kenaikan pangkat pegawai sudah harus dipenuhi sesuai dengan prosedur yang berlaku, namun dalam kenyataannya proses tersebut tertunda dengan berbagai alasan seperti faktor pendidikan, kedisiplinan dan lainlain. Seseorang dapat dipromosikan jabatannya karena yang bersangkutan dapat memperlihatkan prestasi kerja maupun hal-hal lain yang dapat menunjang kenaikan pangkat. Kenaikan Pangkat dapat diberikan jika seseorang sudah menduduki jabatan tertentu atau sebaliknya kerana jabatan orang tersebut dapat diproses kenaikan pangkat.nya. Kenaikan pangkat pilihan diberikan kepada pegawai yang mempunyai prestasi kerja. Sesuai dengan kenyataan selama tahun terakhir ada 17 orang pegawai yang diproses kenaikan pangkat pilihan yakni ada 2 tahun dan 3 tahun dalam jabatan sudah diproses kenaikan pangkat pilihan. Di samping itu juga ada pegawai yang baru menyelesaikan pendidikan strata satu langsung dipromosikan jabatannya.

\section{Perumusan Masalah}

Berdasarkan kepada kajian sebagaimana yang telah dikemukakan dalam latar belakang masalah maka, disini peneliti mencoba merumuskan permasalahannya tentang Pembinaan Pegawai Negeri Sipil pada DinasPendidikan Kabupaten Pidie. Yang antara lain adalah sebagai berikut:

1. Bagaimana pembinaan Pegawai Negeri Sipil pada Dinas Pendidikan Kabupaten Pidie terkait dengan kenaikan pangkat?

2. Faktor-faktor pendorong dan penghambat pembinaan Pegawai Negeri sipil pada Dinas Pendidikan Kabupaten Pidie dalam hal kenaikan pangkat?

\section{Tujuan Penelitian}

Tujuan pelaksanaan penelitian didasarkan pada latar belakang dan perumusan masalah. Sehingga penelitian ini bertujuan sebagai berikut:

1. Untuk mendiskripsikan dan menganalisis pembinaan Pegawai Negeri Sipil pada Dinas Pendidikan Kabupaten Pidie.

2. Untuk mendiskripsikan dan menganalisis faktor pendorong dan penghambat pembinaan Pegawai Negeri Sipil pada Dinas Pendidikan Kabupaten Pidie.

\section{Kegunaan Penelitian \\ Kegunaan Teoritis}

a. Sebagai bahan bandingan untuk penelitian selanjutnya pembinaan Pegawai Negeri Sipil pada Dinas Pendidikan Kabupaten Pidie,

b. Merupakan sumbangan penulis bagi perkembangan Ilmu Administrasi Publik khususnya kajian kebijakan publik dalam mengembangkan konsep-konsep, pengertian, dan implimentasinya untuk mewujudkan kemandirian administrasi publik terutama berkaitan dengan pembinaan Pegawai Negeri Sipil pada Dinas Pendidikan Kabupaten Pidie di masa yang akan datang.

\section{Kegunaan praktis,}

a. Memberikan informasi dan sumbangan pikiran serta masukan bagi para pengambil keputusan pada tingkat Daerah dalam mewujudkan kesetaraan, jenjang dan proposional dalam penetapan kebijakan pembinaan Pegawai,

b. Memberikan masukan bagi Dinas dalam pembinaan Pegawai dalam upaya meningkatkan prestasi kerja 
Hasil Penelitian

\section{Gambaran Umum Lokasi Penelitian}

Dinas Pendidikan Kabupaten Pidie merupakan salah satu Dinas Daerah yang terletak di jalan Tgk.Chik Ditiro Nomor 8 Sigli, tepatnya di Gampong Blang Asan Kecamatan Kota Sigli. Sebelumnya Dinas pendidikan Kabupaten Pidie berlokasi di Jalan Pasi Rawa Sigli. Tanah bangunan Kantor Dinas Pendidikan Kabupaten Pidie yang berlokasi di Jalan Rawa status tanah adalah milik Pemerintah Daerah Kabupaten Pidie, begitu juga tanah bangunan kantor di jalan Tgk.Chik Ditiro juga milik Pemerintah Daerah Kabupaten Pidie.

\section{Organisasi dan tata Kerja Dinas pendidikan Kabupaten Pidie}

Dinas Pendidikan Kabupaten Pidie dipimpin oleh seorang Kepala Dinas yang tunduk dan bertanggung jawab kepada Bupati melalui Sekretaris Daerah. Dinas Pendidikan Kabupaten Pidie pembentukanya di dasarkan kepada Qanun Kabupaten Pidie Nomor 4 Tahun 2013 tentang Perubahan Kedua Atas Qanun Kabupaten Pidie Nomor 4 Tahun 2008 tentang Susunan Organisasi dan tata Kerja Dinas Daerah Kabupaten Pidie, dengan susunan organisasi sebagaimana disebutkan dalam pasal 10 sebagai berikut:

1. Susunan Organisasi Dinas Pendidikan, terdiri dari:
a. Kepala Dinas;
b. Sekretariat;
b. Bidang Bina Program;
c. Bidang Pendidikan Dasar;
d. Bidang Pendidikan Menengah;
e. Bidang Pendidikan Prasekolah dan Luar Sekolah;
f. UPTD;
g. Kelompok Jabatan Fungsional.

2. Sekretariat terdiri dari :
a. Sub Bagian Umum;
b. Sub Bagian Kepegawaian;
c. Sub Bagian Keuangan dan Perlengkapan.

3. Bidang Bina Program terdiri dari:
d. Seksi Data dan Penyusunan Program; dan;
e. Seksi Pengendalian dan Pelaporan.

4. Bidang Pendidikan Dasar terdiri dari:
a. Seksi Pendidikan Dasar dan Luar Biasa;
b. Seksi Pendidikan Sekolah Menengah Pertama dan Luar Biasa;
c. Seksi Kurikulun Pendidikan Dasar.

5. Bidang Pendidikan Menengah terdiri dari :

a. Seksi Pendidikan Sekolah Menengah Atas dan Luar Biasa;

b. Seksi Pendidikan Sekolah Menengah kejuruan dan Luar Biasa;

c. Seksi Kurikulum Pendidikan Menengah.

6. Bidang Pendidikan Prasekolah terdiri dari :

a. Seksi Pendidikan Prasekolah;

b. Seksi Pendidikan Luar Sekolah;

c. Seksi Kurikulum Pendidikan Prasekolah Adapun kedudukan dan tugas Dinas pendidikan Kabupaten Pidie sebagaimana disebutkan dalam pasal 27 adalah :

(1) Kepala Dinas berkedudukan di bawah dan bertanggung jawab kepada Bupati melalui Sekretaris Daerah;

(2) Kepala Dinas mempunyai tugas melakukan tugas umum Pemerintahan di bidang penyelenggaraan Pendidikan Dasar, Pendidikan Lanjutan dan Menengah serta penyelenggaraan Pendidikan Luar Sekolah sesuai dengan Peraturan PerUndang-Undangan.

\section{Pasal 28}

Untuk menyelenggarakan tugas sebagaimana dimaksud dalam Pasal 27, Kepala Dinas mempunyai fungsi :

a. Penyiapan bahan perumusan kebijakan umum dibidang pengelolaan pendidikan;

b. Penyiapan bahan peyusunan rencana dan program dibidang pengelolaan pendidikan;

c. Penyiapan bahan perumusan kebijakan teknis dibidang pengelolaan pendidikan dan pengajaran;

d. Penyusunan program kerja tahunan, jangka menengah dan jangka panjang;

e. Pelaksanaan kebijakan teknis pembinaan pendidikan dan pengajaran tingkat dasar, menengah dan kejuruan;

f. Penyusunan rencana dan program penyelenggaraan pembinaan pendidikan dan pengajaran dasar, menengah dan kejuruan;

g. Pengaturan dan pengawasan penerimaan murid/siswa, ketatlaksanaan alat-alat perlengkapan dan pembangunan gedung, tenaga teknis, dana, ijazah dan perpustakaan pendidikan dasar, menengah, kejuruan dan luar madrasah;

h. Pengelolaan administrasi umum yang meliputi perencanaan, pendataan, kepegawaian, keuangan, peralatan, organisasi dan ketatalaksanaan; 
i. Pelaksanaan pemantauan, evaluasi dan pelaporan pennyelenggaraan pendidikan dan pengajaran;

j. Pelaksanaan koordinasi dengan instansi dan atau lembanga terkait lainnya di bidang pendidikan dan pengajaran;

k. Pembinaan UPTD; dan

1. Pelaksanaan tugas-tugas kkedinasan lainnya yang diberikan oleh Bupati sesuai dengan bidang tugasnya.

Sekretariat

\section{Pasal 29}

(1) Sekretariat adalah unsur pembantu Kepala Dinas dibidang pelayanan dan pengelolaan administrasi;

(2) Sekretariat dipimpin oleh seorang Sekretaris yang berada dibawah dan bertanggung jawab kepada Kepala Dinas.

\section{Pasal 30}

Sekretariat mempunyai tuugas melakukan pembinaan dan pengelolaan administrasi umum, perlengkapan, peralatan, kerumahtanggaan, perpustakaan, keuangan, kepegawaian, ketatalaksanaan, hokum, hubungan masyarakat dan koordinasi penyusun program kerja serta pelayanan administrasikepada semua satuan kerja dilingkungan Dinas.

\section{Pasal 31}

Untukmenyelenggarakan tugas sebagaimana dimaksudkan pasal 30, Sekretariat mempunyai fungsi :

a. Pelaksanaan urusan ketatausahaan, rumah tangga, barang inventaris, asset, perlengkapan, peralatan, pemeliharaan dan perpustakaan;

b. Pelaksanaan pembinaan kepegawaian, organisasi, ketalaksanaan, hokum dan PerUndang-Undangan serta hubungan masyarakat;

c. Pelaksanaan pengawasan dan pengendalian serta evaluasi terhadap pelaksanaan program dan kegiatan;

d. Pelaksanaan koordinasi dengan bidangbidang dan unit pelaksana teknis Dinas dalam penyusunan program; dan

e. Pelaksanaan tugas-tugas kedinasan lainnya yang diberikan oleh Kepala dinas sesuai dengan bidang tugasnya.

\section{Pasal 32}

(1) Sekretariat terdiri dari :
a. Sub Bagian Umum

b. Sub Bagian Kepegawaian; dan

c. Sub Bagian Keuangan dan Perlengkapan.

(2) Masing-masing Sub Bagian sebagaimana dimaksudkan dalam ayat (1), dipimpin oleh seorang Kepala Sub Bagian yang berada dibawah dan bertanggung jawab kepada Sekretaris sesuai dengan bidang tugasnya.

\section{Pasal 33}

(1) Sub Bagian Umum mempunyai tugas melakukan urusan ketatausahaan, rumah tangga, perpustakaan dan arsip, standarisasi dan hubungan masyarakat serta protokoler;

(2) Sub Bagian Kepegawaian mempunyai tugas melakukan pengelolaan administrasi kepegawaian, organisasi, ketatalaksanaan, hokum dan Perundangundangan;

(3) Sub Bagian Keuangan dan Perlengkapan mempunyai tugas melakukan pengelolaan administrasi keuangan, verifikasi, perbendaharaan, pembukuan, pelaporan realisasi fisik dan keuangan, rencana kebutuhan dinas, perlengkapan, peralatan dan pemeliharaan asset Daerah.

\section{Bidang Bina Program}

$$
\text { Pasal } 34
$$

(1) Bidang Bina Program adalah unsure pelaksana teknis dibidang data, penyusunan program, pengendalian dan pelaporan;

(2) Bidang Bina Program dipimpin oleh seorang Kepala Bidang yang berada dibawah dan bertanggung jawab kepada Kepala Dinas melalui Sekretaris.

\section{Pasal 35}

Bidang Bina Program mempunyaii tugas melakukan kegiatan penyusunan program kerja tahunan, jangka panjang, pengkajian, pengembangan, data, informasi, pemantauan, evaluasi dan pelaporan kegiatan pelaksanaan pendidikan.

\section{Pasal 36}

Untuk menyelenggarakan tugas sebagaimana dimaksudkan dalam pasal 35, Bidang Bina Program mempunyai fungsi :

a. Penyusuna program kerja tahunan, jangka menengah dan jangka panjang; 
b. Penyusunan rencana anggaran yang bersumber dari APBK dan sumber lainnya;

c. Pelaksanaan penelitian, pengkajian dari pengembangan program pendidikan;

d. Penyiapan data dan informasi di bidang pelaksanaan program pendidikan;

e. Pemantauan, evaluasi dan pelaporan pelaksanaan program pendidikan;

f. Penyusunan rencana strategi jangka pendek, jangka menengah dan jangka panjang, laporan akuntabilitas kinerja dan rencana kinerja Dinas;

g. Pelaksanaan koordinasi dengan instansi terkait lainnya di bidang bina program; dan

h. Pelaksanaan tugas-tugas kedinasan lainnya yang diberikan oleh Kepala Dinas sesuai dengan tugas dan fungsinya.

\section{Pasal 37}

(1) Bidang Bina Program terdiri dari :

a. Seksi data dan penyusunan program; dan

b. Seksi pengendalian dan pelaporan.

(2) Masing-masing seksi sebagaimana dimaksudkan pada ayat (1), dipimpin oleh seorang Kepala Seksi yang berada dibawah dan bertanggung jawab kepada Kepala Bidang sesuai dengan bidang tugasnya.

\section{Pasal 38}

(1) Seksi data dan penyusuna program mempunyai tugas penyiapan data, informasi penyusunan program dan rencana strategis serta rencana kerja dinas;

(2) Seksi pengedalian dan pelaporan mempunyai tugas melaksanakan pengendalian pemantauan, evaluasi, penyusunan rencana strategis, rencana kerja dan laporan akuntabilitas Dinas.

\section{Bidang Pendidikan Dasar} Pasal 39

(1) Bidang pendidikan Dasar adalah unsure pelaksana teknis dibidang pembinaan dan pengelolaan pendidikan dasar;

(2) Bidang Pendidikan Dasar dipimpin oleh seorang Kepala Bidang yang berada dibawah dan bertanggung jawab kepada Kepala Dinas melalui Sekretaris.

$$
\text { Pasal } 40
$$

Bidang Pendidikan Dasar mempunyai tugas menyiapkan bahan penyusunan pedoman dan petunjuk teknis pelaksanaan pendidikan pra sekolah, pendidikan dasar, pendidikan luar biasa dan penetapan serta pelaksanaan kurikulum pendidikan dasar.

\section{Pasal 41}

Untuk menyelenggarakan tugas sebagaimana dimaksudkan dalam pasal 40, Bidang Pendidikan Dasar mempunyai fungsi :

a. Penyiapan bahan pedoman, pembinaan dan petunjuk teknis penyelenggaraan pendidikan pra sekolah madrasah dasar dan madrasah dasar luar biasa;

b. Pelaksanaan penerapan kurikulum pada pendidikan pra sekolah, madrasah dasar serta pendidikan luar biasa;

b. Pelaksanaan pengawasan dan penilaian teknis pendidikan pra sekolah, pendidikan madrasah dasar dan pedidikan luar sekolah;

c. Pengelolaan TK/SD termasuk sekolah di daerah terpencil, sekolah rintisan/unggulan dan sekolah yang terkena musibah/bencana alam berdasarkan pedoman yang ditetapkan Pemerintah;

d. Pelaksanaan koordinasi dengan instansi terkait lainnya dibidang pendidikan dasar; dan

e. Pelaksanaan tugas-tugas kedinasan lainnya yang diberikan oleh Kepala Dinas sesuai dengan bidang tugasnya.

Pasal 42

(1) Bidang Pendidikan Dasar terdiri dari :

a. Seksi Pendidikan Pra Sekolah;

b. Seksi Pendidikan Dasar dan Pendidikan Luar Biasa; dan

c. Seksi Kurikulum Pendidikan Dasar.

(2) Masing-masing seksi sebagaimana dimaksudkan dalam ayat (1), dipimpin oleh seorang Kepala Seksi yang berada dibawah dan bertanggung jawab kepada Kepala Bidang sesuai dengan bidang tugasnya.

\section{Pasal 43}

1. Seksi Pendidikan Pra Sekolah mempunyai tugas melakukan pembinaan, pengembangan dan penerapan konsep pendidikan pra sekolah yang bersifat kurikuler dan ekstra kurikuler, kemitraan, pengawasan tenaga teknis;

2. Seksi Pendidikan Dasar dan Pendidikan Luar Biasa mempunyai tugas pembinaan 
akademis, pengembangan dan penerapan standarisasi dan kualifikasi serta sarana pendidikan dasar dan luar sekolah;

3. Seksi Kurikulum Pendidikan Dasar mempunyai tugas melakukan pembinaan akademis, pengembangan dan penerapan kurikulum pada pendidikan dasar.

Bidang Pendidikan Lanjutan dan Menengah

Pasal 44

(1) Bidang Pendidikan Lanjutan dan Menengah adalah unsr pelaksana teknis dibidang pembinaan dan pengelolaan pendidikan lanjutan, menengah dan umum;

(2) Bidang Pendidikan lanjutan dan Menengah dipimpin oleh seorang Kepala Bidang yang berada dibawah dan bertanggung jawab kepada Kepala Dinas melalui Sekretaris.

\section{Pasal 45}

Bidang Pendidikan Lanjutan dan Menengah mempunyai tugas mennyiapkan bahan penyusunan pedoman dan petunjuk teknis, pelaksanaan pendidikan lanjutan, menengah dan penerapan kurikulum pendidikan lanjutan, menengah dan umum.

\section{Pasal 46}

Untuk menyelenggarakan tugas sebagaimana dimaksudkan dalam pasal 45, Bidang Pendidikan Lanjutan dan Menengah mempunyai fungsi :

a. Pelaksanaan pengembangan dan penerapan kurikulum pendidikan lanjutan, menengah dan umum;

b. Pembinaan sumber daya tenaga teknis pendidikan lanjutan, menengah dan umum;

c. Pelaksanaan ppemberian sarana pendidikan lanjutan, menengah dan umum;

d. Penetapan standarisasi atau kualifikasi sarana pendidikan lanjutan, menengah dan umum;

b. Pembinaan kesiswaan pendidikan lanjutan, menengah dan umum;

c. Pelaksanaan pengelolaan dana dekonsenrtasi dan APBK;

d. Pelaksanaan koordinasi dengan instansi dan atau lembaga terkait lainnya dibidang pendidikan lanjutan, menengan; dan e. Pelaksanaan tugas-tugas kedinasan lainnya yang diberikan oleh Kepala Dinas sesuai dengan tugas dan fungsinya.

\section{Pasal 47}

(1) Bidang Pendidikan Lanjutan dan Menengah terdiri dari :
a. Seksi Pendidikan Lanjutan;
b. Seksi Pendidikan Menengah; dan
c. Seksi Kurikulum Pendidikan Lanjutan dan Menengah.

(2) Masing-masing seksi sebagaimana dimaksudkan pada ayat (1), dipimpin oleh seorang Kepala Seksi yang berada dibawah dan bertanggung jawab kepada Kepala Bidang sesuai dengan tugas dan fungsinya.

\section{Pasal 48}

(1) Seksi Pendidikan lanjutan mempunyai tugas melakukan pembinaan, pengembangan, akademis dan sarana pendidikan lanjutan;

(2) Seksi Pendidikan Menengah mempunyai tugas melakukan pembinaan, pengembangan akademis, dan sarana pendidikan menengah;

(3) Seksi Kurikulum Pendidikan Lanjutan dan Menengah mempunyai tugas melakukan pembinaan akademis, pengembangan dan penerapan kurikulum pendidikan lanjutan dan menengah.

Bidang Pendidikan Kejuruan dan Luar Sekolah

Pasal 49

(1) Bidang Pendidikan Kejuruan dan Luar Sekolah adalah unsure pelaksana teknis dibidang pembinaan dan pengelolaan pendidikan kejuruan dan uar sekolah;

(2) Bidang Pendidikan Kejuruan dan Luar Sekolah dipimpin oleh seorang Kepala Bidang yang berada dibawah dan bertanggung jawab kepada Kepala Dinas melallui Sekretaris.

\section{Pasal 50}

Bidang Pendidikan Kejuruan dan Luar Sekolah mempunyai tugas pembinaan, pengembangan dan penerapan kurikulum, pembinaan tenaga pendidikan, pembinaan sarana pendidikan kejuruan dan luar sekolah.

Pasal 51

Untuk menyelenggarakan tugas sebagaimana dimaksudkan dalam pasal 50, 
Bidang Pendidikan Kejuruan dan Luar Sekolah mempunyai fungsi :

a. Pembinaan penyelenggaraan kegiatan pendidikan kejuruan dan luar sekolah;

b. Penyusunan program pedoman dan petunjuk teknis serta pelaksanaan pengawasan pendidikan kejuruan dan luar sekolah;

c. Pembinaan dan perencanaan kebutuhan tenaga kependidikan berdasarkan data dan informasi serta sarana pendidikan kejuruan dan luar sekolah;

d. Pelaksanaan pengawasan dan penilaian teknis pendidikan kejuruan dan luar sekolah;

e. Pelaksanaan koordinasi dengan instansi atau lembaga terkaiy lainnya di bidang pendidikan kejuruan dan luar sekolah; dan

f. Pelaksanaan tugas-tugas kedinasan lainnya yang diberikan oleh Kepala Dinas sesuai dengan bidang tugasnya.

Pasal 52

Bidang Kejuruan dan Luar Sekolah terdiri dari :

a. Seksi pendidikan kejuruan;

b. Seksi pendidikan luar sekolah; dan

c. Seksi kurikulum pendidikan kejuruan.

Masing-masing seksi sebagaimana dimaksudkan di atas, dipimpin oleh seorang Kepala Seksi yang berada dibawah dan bertanggung jawab kepada Kepala Bidang sesuai dengan bidang tugasnya.

Pasal 53

(1) Seksi Pendidikan Kejuruan mempunyai tugas melakukan pembinaan akademis, pengembangan dan pengawasan tenaga teknis serta pembinaan sarana pendidikan Kejuruan;

(2) Seksi Pendidikan Luar Sekolah mempunyai tugas melakukan pembinaan dan pengembangan akademis, yang bersifat kurikuler dan ekstra kurikuler, kemiitraan, pengawasan tenaga teknis pembinaan sarana pendidikan luar sekolah;

(3) Seksi Kurikulum Pendidikan Kejuruan mempunyai tugas melakukan pembinaan akademis, pengembangan dan penerapan kurikulum, pengesahan supervise klinis kurikulum pendidikan kejuruan.

\section{Kepegawaian}

Keadaan pegawai Dinas Pendidikan Kabupaten Pidie sebagaimana data yang dijumpai dalam Daftar Urut Kepangkatan seluruhnya berjumlah 72 orang Berdasarkan data tersebut dapat diklasifikasikan berdasarkan jenis kelamin dalam tabel berikut :

Tabel -1

Klasifikasi Pegawai Dinas pendidikan Kabupaten Pidie

berdasarkan jenis kelamin

\begin{tabular}{|c|c|c|c|}
\hline No. & $\begin{array}{c}\text { Jenis } \\
\text { Kelamin }\end{array}$ & Jumlah (org) & Persentasi (\%) \\
\hline 1 & 2 & 3 & 5 \\
\hline 1. & Laki-Laki & 43 & 59.72 \\
2. & Perempuan & 29 & 40.27 \\
\hline \multicolumn{2}{|c|}{ Jumlah } & 72 & - \\
\hline
\end{tabular}

Dari data yang telah dikemukakan diatas, maka dapat diambil suatu kesimpulan bahwa keadaan pegawai Dinas Pendidikan Kabupaten Pidie untuk saat ini lebih didominasi oleh pegawai laki-laki yaitu sebanyak 59,72 \%. Selanjutnya akan disajikan keadaan pegawai yang ditinjau berdasarkan golongan ruang dan Jenis kwelamin.

Tabel - 2

Rekapitulasi Keadaan pegawai Negeri Sipil Berdasarkan Golongan dan Ruang Dinas pendidikan Kabupaten Pidie

\begin{tabular}{|c|c|c|c|}
\hline No & Golongan/Ruang & Jumlah & Persentase (\%) \\
\hline 1 & 2 & 3 & 4 \\
\hline 1 & IV & 11 & 15.28 \\
2 & III & 51 & 70.83 \\
3 & IV & 10 & 13.89 \\
\hline \multicolumn{2}{|c|}{ Jumlah } & 72 & 100 \\
\hline
\end{tabular}

Dengan menitik beratkan pada data yang telah dikemukakan diatas, maka dapat dikatakan bahwa lebih dari lima puluh persen pegawai Dinas Pendidikan Kabupaten Pidie masih dalam pangkat atau golongan III (penata). Berikut ini akan dikemukakan pula klasifikasi keadaan Pegawai Negeri Sipil pada Dinas Pendidikan Kabupaten Pidie yang ditinjau dari latar belakang pendidikan akan disajikan dalam tabel berikut:

Tabel - 3

Rekapitulasi Pegawai Dinas pendidikan Kabupaten Pidie Berdasarkan latar Belakang Pendidikan

\begin{tabular}{|c|c|c|c|}
\hline No. & Jenjang Pendidikan & Jumlah (org) & Persentase \% \\
\hline 1 & 2 & 3 & 4 \\
\hline 1 & Pasca Sarjana & 8 & 11.11 \\
2 & Sarjana & 45 & 62.50 \\
3 & D-3 & 4 & 5.55 \\
4 & D-2 & 1 & 1.39 \\
5 & S L T A & 14 & 19.44 \\
\hline \multicolumn{2}{|r|}{ J u m l a h } & 72 & 100 \\
\hline
\end{tabular}


Dari uraian diatas, maka dapat dikatakan bahwa tingkat pendidikan Pegawai Negeri Sipil Dinas Pendidikan Kabupaten Pidie lebih didominasi oleh pegawai yang berlatar belakang pendidikan sarjana, dan masih dijumpai pegawai yang berlatar belakang pendidikan Sekolah Lanjutan Tingkat Atas (SLTA). Selanjutnya akan disajikan keadaan Pegawai Negeri Sipil pada Dinas Pendidikan Kabupaten Pidie yang akan disajikan dalam tabel berikut ini:

TABEL- 4

Rekapitulasi PNS Berdasarkan eselonering dan jenis Kelamin Dinas Pendidikan Kabupaten Pidie

\begin{tabular}{|c|c|c|c|c|}
\hline No & $\begin{array}{c}\text { Eselonerin } \\
\mathrm{g}\end{array}$ & $\begin{array}{c}\text { Laki- } \\
\text { laki }\end{array}$ & Perempuan & Jumlah \\
\hline 1 & 2 & 3 & 4 & 6 \\
\hline 1 & II & 1 & - & 1 \\
2 & III & 5 & - & 5 \\
3 & IV & 11 & 3 & 14 \\
\hline \multicolumn{2}{|c|}{ Jumlah } & 17 & 3 & 20 \\
\hline
\end{tabular}

Sebagaimana data yang diperoleh dari hasil penelitian lapangan menunjukkan bahwa ada sebagian Pegawai Negeri Sipil Dinas Pendidikan Kabupaten Pidie yang telah mengikuti pelatihan penjenjangan hal ini dapat dilihat dalam tabel berikut :

\section{Tabel - 5}

Latihan Penjenjangan yang telah diikuti oleh PNS Dinas Pendidikan Kabupaten Pidie

\begin{tabular}{|c|l|c|}
\hline No & \multicolumn{1}{|c|}{ Tingkat Penjenjangan } & Jumlah \\
\hline 1 & \multicolumn{1}{|c|}{2} & 3 \\
\hline 1 & Diklat Pim III & 5 \\
2 & Diklat Pim IV & 9 \\
3 & ADUM & 3 \\
4 & Bintek Tata Masalah Dinas, Diklat & 1 \\
5 & ESQ & 1 \\
\hline \multicolumn{2}{|c|}{ Jumlah } & 19 \\
\hline
\end{tabular}

Pegawai Negeri Sipil Dinas pendidikan Kabupaten Pidie seluruhnya berjumlah 72 orang, dari jumlah pegawai tersebut dapat dikaji masa kerja dari sebagaimana tertera dalam tabel berikut :

Tabel -6

Rekapitulasi PNS Dinas pendidikan Kabupaten Pidie Berdasarkan masa Kerja

\begin{tabular}{|c|c|c|c|}
\hline No & Masa Kerja & Jumlah (org) & Persentase (\%) \\
\hline 1 & 2 & 3 & 4 \\
\hline 1 & 1 s /d 5 Tahun & 3 & 4.17 \\
\hline 2 & 6 s /d 10 Tahun & 14 & 19.44 \\
\hline 3 & 11 s/d 15 Tahun & 16 & 22.22 \\
\hline 4 & 16 s/d 20 Tahun & 17 & 23.61 \\
\hline
\end{tabular}

\begin{tabular}{|c|l|c|c|}
\hline 5 & $21 \mathrm{~s} / \mathrm{d} 25$ Tahun & 14 & 19.44 \\
\hline 6 & $\begin{array}{l}\text { Di atas 25 } \\
\text { Tahun }\end{array}$ & 8 & 11.11 \\
\hline \multicolumn{2}{|l|}{ Jumlah } & 72 & 100 \\
\hline
\end{tabular}

\section{Disiplin}

Disiplin Pegawai Negeri Sipil merupa-kan kesanggupan Pegawai Negeri Sipil untuk menaati kewajiban \& menghindari larangan yang ditetapkan perundang-undangan atau peraturan kedinasan. Pelanggaran disiplin Pegawai Negeri Sipil : setiap ucapan, tulisan atau perbuatan Pegawai Negeri Sipil yang tidak menaati kewajiban atau melanggar larangan ketentuan disiplin Pegawai Negeri Sipil baik di dalam maupun di luar jam kerja. Peraturan Disiplin Pegawai Negeri Sipil diatur dalam Peraturan Pemerintah No.53 tahun 2010, yang mengatur kewajiban, larangan, hukuman bagi Pegawai Negeri Sipil yang terbukti melakukan pelanggaran disiplin.Tingkat Hukuman Disiplin

1. Hukuman disiplin Ringan

a) Teguran lisan

b) Teguran tertulis

c) Pernyataan tidak puas secara tertulis

2. Hukuman Disiplin Sedang

a) Tunda Kenaikan Gaji Berkala selama 1 tahun

b) Tunda kenaikan pangkat selama 1 tahun

c) Turun pangkat setingkat lebih rendah selama 1 tahun.

3. Hukuman Disiplin Berat

a). Penurunan pangkat setingkat lebih rendah selama 3 (tiga) tahun

b). Pemindahan dalam rangka penurunan jabatan setingkat lebih rendah

c). Pembebasan dari jabatan

d). Pemberhentian dengan hormat tidak atas permintaan sendiri sebagai PNS

e). Pemberhentian tidak dengan hormat sebagai PNS

Dalam sebuah organisasi baik organisasi publik maupun swasta disiplin sangat diperlukan agar tidak terjadi kelalaian atau pemborosan dalam menjalankan suatu pekerjaan. Disiplin adalah suatu keadaan tata tertib di mana orangorang yang bergabung dalam suatu organisasi tunduk pada peraturan-peraturan yang telah ada dengan senang hati. Menurut pendapat Gordon S. Watkins dalam Moenir (2012 :94), menjelaskan disiplin sebagai suatu kondisi atau sikap yang ada pada semua anggota organisasi yang tunduk dan taat pada aturan organisasi. Jadi disiplin merupakan suatu bentuk ketaatan 
terhadap aturan baik tertulis maupun tidak tertulis yang telah ditetapkan. Dalam pelaksanaan tugas disiplin terdiri atau dua jenis yaitu disiplin waktu dan disiplin perbuatan. Kedua jenis disiplin tersebut merupakan kesatuan yang tak dapat dipisahkan serta saling mempengaruhi.

Disiplin waktu tanpa disertai disiplin kerja tidak ada artinya, dengan kata lain tidak ada hasil sesuai dengan ketentuan organisasi. Sebaliknya disiplin kerja tanpa didasari dengan disiplin waktu tidak ada manfaatnya. Oleh karena itu usaha pendisiplinan tidak dapat dilakukan separuh-separuh melainkan harus serentak kedua-duanya. Pada umumnya disiplin yang baik terdapat apabila pegawai datang ke kantor atau organisasi kerja dengan teratur dan tepat pada waktunya, apabila mereka berpakaian serba baik pada tempat pekerjaannya, apabila menggunakan bahan-bahan dan perlengkapan dengan hati-hati, apabila mereka menghasilkan jumlah dan kualitas pekerjaan yang memuaskan dan mengikuti cara kerja yang ditentukan oleh organisasi kerja dan menyelesaikan dengan semangat yang baik.

Untuk kelancaran kegiatan organisasi dalam produktivitas untuk mencapai target yang diharapkan, para tenaga kerja perlu memperoleh pembinaan disiplin kerja dan merupakan fungsi yang harus dilaksanakan manajemen pada semua hirarki terhadap organisasi. Pembinaan disiplin kerja yang terus menerus dilakukan manajemen agar para tenaga kerja termotivasi untuk melakukan tindakan disiplin bukan karena sanksi tetapi melainkan didorong untuk menjadi kedisplinan yang dapat timbul bagi dirinya dan lingkungnnya dalam sebuah prerusahaan atau organisasi. Menurut Handoko (2012 :210), secara rinci disiplin dapat dibagi dalam tiga bentuk yaitu:

1. Disiplin Preventif, yaitu kegiatan yang dilakukan untuk mendorong para karyawan agar mengikuti berbagai standar dan aturan dimana peraturan tersebut harus ditaati sehingga berbagai penyelewengan dapat dicegah dan sasaran dapat tercapai sebagaimana mestinya. Sasaran pokoknya adalah untuk mendorong disiplin diri para karyawan itu sendiri dengan cara ini para karyawan menjaga disiplin diri mereka bukan semata-mata dipaksa manajemennya,

2. Disiplin Korektif, yaitu kegiatan yang diambil untuk menangani pelanggaran terhadap aturan-atauran dan mencoba untuk menghindari pelanggaran-pelanggaran lebih lanjut. Kegiatan korektif ini sering berupa suatu bentuk hukuman dan disebut tindakan-tindakan disiplin (disiplinary action). Sebagai contoh kedisiplinan biasanya berupa peringatan (skorsing),

3. Disiplin Progresif, kebijakan disiplin berarti memberikan hukuman yang lebih berat terhadap pelanggaran yang berulang dan mungkin manajemen untuk membantu karyawan memperbaiki kesalahan. Sebuah contoh disiplin secara progresif adalah sebagai berikut:

a. Teguran secara lisan oleh penyedia,

b. Teguran tertulis dengan catatan dalam file personalia,

c. Skorsing dari pekerjaan dari satu sampai tiga hari,

d. Skorsing satu minggu atau lebih lama,

e. Diturunkan pangkatnya (demosi) dan juga dipecat.

Sebagaimana diketahui bahwa sistem kepegawaian memiliki pengertian yang lebih luas, bukan hanya berkaitan dengan sistem Kenaikan pangkat pegawai melaikan juga meliputi perencanaan, pembinaan karier, pengendalian dan sebagainya. Kebijaksanaan manajemen Pegawai Negeri Sipil yang meliputi beberapa hal sebagaimana yang telah dikemukakan sebelumnya pengembangan kwalitas pegawai negeri sipil,pemindahan gaji dan lain-lain. Semuanya itu ditetapkan secara seragam dengan harapan dapat diciptakan kualitas pegawai negeri sipil yang seragam diseluruh Indonesia dan memudahkan penyelenggaraan manajemen kepegawaian, mewujudkan keseragaman perlakuan dan jaminan kapastian hukum bagi seluruh pegawai negeri sipil yang ada. Tujuan utama dari pembinaan pegawai negeri sipil terutama dalam kedisiplinan merupakan suatu hal yang dilakukan agar setiap pegawai dapat mentaati peraturan disiplin maupun peraturan-peraturan lainnya agar lebih berdaya guna, berhasil guna dan tepat guna, sehingga dapat diciptakan, dipelihara dan dikembangkan suasana kerja yang menyenangkan diantara para pegawai, dan pengembangan yang maksimal bagi pegawai pegawai tersebut.

Manajemen kepegawaian pada hakikatnya melakukan dua fungsi/kegiatan pokok yang dilakukan dalam suatu organisasi yaitu fungsi manajerian dan fungsi operatif (teknis). Ada dua aspek aktivitas besar yang menjadi lingkup manajemen kepagawaian, yaitu disatu pihak terdapat rangkaian aktivitas perencanaan, 
pengorganisasian, pengarahan dan pengendalian (merupakan fungsi manajerian) dan dipihak lain terdapat rangkaian aktivitas pengadaan, pengembangan, kompensasi, integrasi, pemeliharaan dan pemberhantian (merupakan fungsi operatif administrasi kepegawaian). Fungsi ini dilakukan untuk memperoleh jumlah dan jenis pegawai yang tepat untuk mencapai tujuan organisasi. Fungsi ini berkaitan dengan penentuan kebutuhan pegawai dan penarikannya, seleksi dan penempatannya. Kabutuhan pegawai harus dianalisis dari segi mutu dan jumlah setiap jenis pegawai yang dibutuhkan. Rancangan dan analisis pekerjaan merupakan proses dasar yang memberikan informasi untuk penetapan standar mutu pegawai.

Sebagai hasil langsung dari proses ini penciptaan uraian pekerjaan dan standar yang dapat dipergunakan sehingga kita dapat mengukur para pelamar pekerjaan. Penentuan pegawai yang diperlukan harus berdasarkan pada tugas-tugas yang tercantum pada rancangan pekerjaan yang ditentukan sebelumnya. Penentuan ini merupakan keputusan yang dipengaruhi oleh tujuan pimpinan dalam memenuhi kebutuhan pegawai. Dengan menitik beratkan pada uraian-uraian sebelumnya, maka dalam hal ini berkenaan dengan penerapan disiplin Pegawai Negeri Sipil pada Dinas pendidikan Kabupaten Pidie juga membutuhkan pegawai yang lebih profesional dalam menjalankan tugas-tugas yang telah dibebankan kepadanya. Di samping itu pula perlu diberikan berbagai pelatihan-pelatihan atau pendidikan tambahan dalam upaya peningkatan prestasi kerja serta pembinaan oleh pimpinan secara kontinue agar semua tugas dapat diselesaikan secara berdaya guna dan berhasil guna.

Tujuan pokok dari manajemen Kepegawaian merupakan suatu usaha yang harus dilakukan untuk memperoleh, memelihara dan membina pegawai ke arah kerja yang menyenangkan dengan syarat kerja yang memuaskan, bagaimana memanfaatkan pegawai secara efisien, mensuplai pegawai dalam kualitas dan kuantitas yang dapat dipertanggung jawabkan. Pembinaan pegawai dilandasi jiwa bahwa Pegawai Negeri Sipil sebagai warga negara, abdi negara dan abdi masyarakat yang penuh kesetiaan dan pengabdian kepada Pancasila dan Undang-Undang Dasar 1945 Negara dan Pemerintah serta bersatu padu, bermental baik, berwibawa, berdaya guna bersih, bermutu tinggi dan sadar akan tanggung jawab untuk menyelenggarakan tugas-tugas pemerintahan dan pembangunan.

Pembinaan pegawai merupakan totalitas kegiatan yang meliputi perencanaan, pengaturan dan penggunaan pegawai sehingga menjadi pegawai yang mampu mengemban tugas menurut bidangnya masing-masing agar dapat mencapai prestasi kerja yang efektif dan efisien. Perencanaan pegawai merupakan suatu tahapan yang sangat penting untuk menentukan kualitas dan kuantitas pegawai, guna memenuhi kebutuhan organisasi untuk masa sekarang dan masa yang akan dating. Perhatian pemerintah sangatlah besar dalam usaha menuju pada penyempurnaan aparatur pemerintah yang bersih dan berwibawa, hal ini dilakukan mengingat betapa penting peranan aparatur pemerintah dalam penyelenggaraan urusan-urusan pemerintahan maupun tugas-tugas pembangunan, di dalam mencapai tujuan nasional. Salah satu aspek dalam usaha melaksanakan penyempurnaan tersebut adalah dengan jelan melakukan pembinaan terhadap Pegawai Negeri Sipil.

Kebijakan pemerintah dalam rangka usaha pembinaan terhadap Pegawai Negeri Sipil tersebut berorientasi dari pengalamanpengalaman yang dialami oleh Pegawai Negeri Sipil pada masa yang lalu. Oleh sebab itu pada saat ini pembinaan pegawai negeri sipil telah dilaksanakan secara sadar, berencana terarah dan pada dasarnya merupakan upaya pendidikan baik formal maupun non formal dalam rangka meningkatkan dan mengembangkan dirinya kearah pencapaian tujuan organisasi. Selanjutnya diharapkan dapat menambah pengetahuan dan ketrampilan yang sesuai dengan bakat dan prosedur yang terdapat dalam pembinaan yang dilaksanakan. Berdasarkan hasil wawancara penulis dengan salah seorang Pegawai Kasubbag Kepegawaian Dinas Pendidikan Kabupaten Pidie jika ada pegawain yang melanggar ketentuan disipin hanya dilakukan teguran lisan dan teguran tertulis dan setelah itu pegawai yang bersangkutan dilakukan pembinaan agar tidak lagi mengulangi kesalahan yang sama (hasil wawancara tanggal 20 Maret 2016).

Teguran yang pernah diberikan kepada beberapa orang pegawai Dinas pendidikan yang melanggar peraturan disiplin sebagaimana data yang diperoleh antara lain adalah 
Tabel -7

Teguran yang pernah diberikan kepada Pegawai Dinas pendidikan Kabupaten Pidie yang melanggar ketentuan Disiplin

\begin{tabular}{|c|c|c|c|}
\hline No & Uraian & Jumlah & Ket. \\
\hline 1 & 2 & 3 & 4 \\
\hline 1 & Teguran Lisan & 2 & - \\
\hline 2 & Teguran tertulis & 1 & - \\
\hline \multicolumn{2}{|c|}{ Jumlah } & 3 & - \\
\hline
\end{tabular}

Sejak diberlakukan absen elektrik dengan sistem sidik jari setiap pegawai harus melakukan sidik jari pada jam masuk dan pulang kantor sesuai dengan jadwal yang telah ditentukan dan pada jam kerja tidak dibenarkan ada pegawai yang keluar kantor tanpa ada keperluan yang jelas, karena sertiap pimpinan pada masingmasing bidang selalu mengontrol bawahannya kemana mereka kalau tidak ada di dalam kantor. Oleh karena itu pelanggaran disiplin sangat kecil sekali sejak diberlakukan absen sidik jari tersebut. Di samping itu pegawai juga masuk dan pulang kantor sesuai dengan jadwal yang telah ditetapkan.

\section{Sarana dan Prasarana}

Berkenaan dengan sarana dan prasarana/Perlengkapan yang dimiliki oleh Dinas Pendidikan Kabupaten Pidie sebagaimana data yang diperoleh dari hasil penelitian relative banyak sehingga penulis tidak mungkin menguraikan satu persatu, oleh karena itu penulis melampirkan jumlah dan jenis perlengkapan tersebut dalam lampiran Tesis ini

\section{Pembahasan}

Kenaikan pangkat bagi seorang Pegawai Negeri Sipil dilakukan berdasarkan sistem kenaikan pangkat reguler dan sistem kenaikan pangkat pilihan dan masa kenaikan pangkat Pegawai Negeri Sipil ditetapkan pada tanggal 1 April dan 1 Oktober setiap tahunnya. Kenaikan pangkat pertama sekali sebagaimana yang telah disebutkan diatas maka Pegawai Negeri Sipil dihitung sejak pengangkatan sebagai Calon Pegawai Negeri Sipil. Kenaikan pangkat reguler bagi seoarang Pegawai Negeri Sipil sebagaimana ditetapkan dalam pasal 6 Peraturan Pemerintah Nomor 12 Tahun 2002 tentang kenaikan pangkat Pegawai Negeri Sipil adalah Kenaikan pangkat reguler yang diberikan kepada Pegawai Negeri Sipil yang:

a. Tidak menduduki jabatan struktural atau jabatan fungsional tertentu, b. Melaksanakan tugas belajar sebelumnya tidak menduduki jabatan struktural atau jabatan fungsional tertentu,

c. Diperkerjakan atau diperbantukan secara penuh diluar intansi induk, tidak menduduki jabatan struktural atau jabatan fungsional tertentu.

Kemudian dalam pasal 8 disebutkan pula bahwa kenaikan pangkat pilihan yang diberikan kepada Pegawai Negeri Sipil yang:

a. Menduduki jabatan struktural / jabatan fungsional tertentu,

b. Menduduki jabatan tertentu, pengangkatannya ditetapkan dengan Keppres,

c. Menunjukkan prestasi kerja luar biasa baiknya,

d. Menentukan penemuan baru yang bermanfaat bagi negara,

e. Diangkat menjadi pejabat negara,

f. Memperoleh surat tanda tamat belajar atau ijazah,

g. Melaksanakan tugas belajar dan sebelumnya menduduki jabatan struktural atau jabatan fungsional,

h. Telah selesaikan mengikuti dan lulus tugas belajar

i. Diperkerjakan atau diperbantukan secara penuh diluar intansi induknya yang diangkat dalam jabatan pimpinan atau jabatan fungsional tertentu.

Dinas pendidikan Kabupaten Pidie dalam melakukan proses kenaikan pangkat pegawai tetap didasarkan kepada peraturan perundangundangan yang berlaku, namun demikian meskipun telah ada ketentuan atau syarat-syarat yang harus dipenuhi terjadi penyimpangan dalam kenaikan pangkat :

Berdasarkan hasil wawancara penulis dengan salah seorang pegawai Sub Bagian kepegawai ada tiga orang pegawai yang terjadi penyimpangan dalam kenaikan pangkat yaitu Kasi PLS, Kasi Prasekolah dan Sekretaris Dinas ketiga orang tersebut dipromosikan jabatannya terlebih dahulu baru diusul kenaikan pangkat ( hasil wawancara tanggal 22 Maret 2016)

Dasar promosi bagi pengangkatan pegawai dalam suatu jabatan tertentu adalah prestasi kerja, Disiplin, Loyalitas, Daftar Urut Kepangkatan (DUK) yang dikatagorikan baik, dan pegawai yang akan dipromosi harus mempunyai perilaku yang tidak tercela serta telah lulus dari diklat penjenjangan. Selain hal tersebut, pertimbangan dari Badan Pertimbangan Jabatan dan Kepengkatan (Baperjakat), manjadi 
dasar bagi penunjukan seorang pegawai untuk menduduki jabatan yang lebih tinggi. Pada umumnya pegawai yang akan dipromosikan harus memenuhi persyaratan pendidikan dan prestasi kerja yang baik, sehingga setelah dipromosikan akan terjadi peningkatan kinerja. Pegawai yang diberikan suatu kepercayaan, yaitu promosi harus memenuhi persyaratan yang ditentukan antara lain : a) Pangkat/golongan yang telah memenuhi syarat, b) Disiplin ilmu/latar belakang pendidikan formal, c) Mempunyai kinerja/prestasi kerja yang lebih baik, d) Telah mengikuti Diklat struktural/fungsional, e) Memerhatikan DUK, f) DP-3 paling tidak bernilai baik, dan g) Usia.

Pada dasarnya setiap pegawai mempunyai jabatan karena mereka direkrut berdasarkan berdasarkan kebutuhan untuk melaksanakan tugas dan fungsi yang ada dalam organisasi. Apabila hal ini diakui, maka tidak akan ada seorangpun pegawai yang tidak mempunyai jabatan, apapun jenis jabatannya. Penempatan pegawai Negeri Sipil dalam jabatan dilaksanakan berdasarkan prinsip profesionalitas sesuai dengan kompetensi, prestasi kerja dan jenjang pangkat yang ditetapkan untuk jabatan itu serta syarat objektif lainnya tanpa bembedakan jenis kelamin, suku, agama, ras atau golongan. Penempatan pegawai tidak selalu berarti penempatan pegawai baru, tetapi bisa pula berarti sebagai promosi, mutasi, dan demosi. Promosi adalah penempatan pegawai pada jabatan yang lebih tinggi dengan wewenang dan tanggung jawab yang lebih tinggi dan penghasilan yang lebih tinggi pula. Promosi harus beradasrkan pada pertimbanganpertimbangan objektif. Pada umumnya ada dua kriteria utama dalam mempertimbangkan seseorang untuk dipromosikan, yaitu prestasi kerja dan senioritas

Di samping promosi jabatan sebagaimana yang telah disebutkan di atas, Dinas Pendidikan Kabupaten Pidie dalam proses kenaikan pangkat ada pegawai yang tertunda kenaikan pangkat, hal ini sesuai dengan data dalam Daftar Urut Kepangkatan pegawai ada Pegawai negeri Sipil yang tertunda kenaikan pangkat sampai dengan 14 tahun mulai tahun 2001 sampai tahun 2015 baru bisa diproses kenaikan pangkat ada yang tertunda kenaikan pangkat sampai 7 tahun, 9 tahun dan 10 tahun, hal ini dikarenakan rata-rata faktor pendidikan yang tidak mendukung kenaikan pangka pegawai. Ada beberapa faktor pendorong dan penghambat pembinaan Pegawai negeri Sipil pada Dinas pendidikan Kabupaten Pidie.

\section{Faktor Pendorong \\ Pembinaan Kepagawaian}

Pegawai Negeri Sipil merupakan salah satu unsur Aparatur Negara yang berperan penting dalam pelaksanaan tugas umum pemerintahan. Pembinaan Pegawai Negeri Sipil perlu dilakukan agar kemampuan, ketrampilan, potensi, motivasi serta prestasi kerja dapat dikembangkan secara maksimal, meskipun para pegawai telah menjalani orientasi secara komprehensif, namun mereka jarang melaksanakan pekerjaannya dengan memuaskan. Untuk mengatasi hal tersebut perlu dirancang suatu pola dasar karier Pegawai Negeri Sip.il yang sesuai dengan misi. visi dan fungsi organisasi, budaya organisasi dan kondisi perangkat pendukung sistem kepegawaian yang berlaku bagi organisasi tersebut.

Untuk mencapai Pegawai Negeri Sipil sebagaimana yang telah disebutkan di atas, maka Pegawai Negeri Sipil perlu dibina dengan sebaik-baiknya.Dalam Undang-Undang Nomor 8 Tahun 1974 sebagaimana telah diubah dengan Undang-Undang Nomor 43 Tahun 1999 tentang Pokok-Pokok Kepegawaian dalam pembinaan Pegawai Negeri Sipil dapat didasarkan pada sistem karier dan sistem prestasi kerja. Siastem karier merupakan sustu sistem kepegawaian di mana untuk pengangkatan pertama didasarkan atas kecakapan yang bersangkutan, sedang dalam pengembangan lebih lanjut, masa kerja kesetiaan, pengabdian dan syarat objektif lainnya.

Sedangkan sistem prestasi kerja merupakan suatu sistem kepegawaian di mana pengangkatan seseorang untuk menduduki suatu jabatan atau untuk naik pangkat didasarkan atas kecakapan dan prestasi yang dicapai oleh pegawai tersebut. Kecakapan harus dibuktikan dengan lulus ujian dinas dan prestasi dibuktikan secara nyata. Ada beberapa jenis pembinaan Pegawai Negeri Sipil yang dapat dilakukan antara lain :

\section{Pembinaan Pangkat}

Pangkat adalah kedudukan yang menunjukkan tingkat seorang pegawai negeri dalam rangkaian susuan kepegawaian dan digunakan sebagai dasar penggajian. Setiap pegawai Negeri Sipil yang telah memenuhi syarat-syarat yang ditentukan dapat diberikan kenaikan pangkat.. Kenaikan pangkat adlah 
penghargaan yang diberikan atas pengabdian Pegawai Negeri Sipil yang bersangkutan terhadap negara.. Di samping itu kenaikan pangkat juga merupakan dorongan kepada Pegawai Negeri Sipil untuk lebih meningkatkan pengabdian Dinas pendidikan Kabupaten Pidie telah melakukan pembinaan pegawai melalui proses kenaikan pangkat sesuai dengan prosedur yang berlaku, namun demikian ada beberapa orang pegawai yang tidak dapat diproses kenaikan pangkat sesuai dengan ketentuan yang ada karena terkendala dari faktor pendidikan pegawai yang bersangkutan sehingga harus menungga dalam jangka waktu yang lama sehingga proses kenaikan pangkat dapat dilaksanakan

\section{Pembinaan Jabatan}

Pada dasarnya setiap Pegawai Negeri Sipil diserahi tugas dalam jabatan tertentu yang menjadi tanggung jawabnya. Jabatan adalah kedudukan yang menunjuukan tugas, tanggung jawab, wewenang dan hak seorang pegawai Negeri Sipil. Prinsip penempatan pegawai dalam jabatan adalah menempatkan Pegawai Negeri Sipil yang tepat pada jabatan yang tepat. Untuk itu harus ada ukuran yang sama yang dapat dijadikan dasar dalam suatu jabatan. Ukuran tersebut antara lain penilaian pelaksanaan pekerjaan, keahlian, perhatian, daftar Urut kepangkatan, Kesetian dan Pengabdian, pengalaman, dapat dipercaya dan kemungkinan pengembangan yang bersangkutan. Dalam hal pembinaan jabatan terhadap Pegawai Dinas pendidikan Kabupaten Pidie telah melaksanakan hal tersebut, namun demikian jika diperhatikan dalam pembinaan jabatan terhadap pegawai masih dirasakan kurang karena penampatan pegawai ada yang kurang sesuai dengan bidang keahliannya seperti halnya Kepala Sub Bagian Kepagawai bidang keahliannya atau latar belakang pendidikan adalah Insinyur Pertanian.

\section{Pembinaan Disiplin}

Disiplin adalah suatu sikap mental yang berupa kewajiban/keharusan untuk mentaati segala ketentuan perundang-undangan, peraturan kedinasan dan perintah atasan yang berwenang Peraturan Pemerintah Republik Indonesia Nomor 53 Tahun 2010 tentang peraturan disiplin Pegawai Negeri Sipil.mengatur tentang kewajiban, larangan dan sanksi apabila kewajiban tidak ditaati bagi yang melanggar. Kewajiban mengatur hal-hal yang harus dilakukan oleh pegawai Negeri Sipil, sedang larangan mengatur hal-hal yang tidak boleh dilakukan. Apabila Pegawai Negeri Sipil tidak melakukan kewajiban dan melakukan hal-hal yang dilarang kepadanya dikenakan sanksi hukuman.

Dinas pendidikan Kabupaten Pidie telah memberlakukan peraturan disiplin kepada semua Pegawai Negeri Sipil dilingkungan Dinas, meskipun telah diberlakukan absen sidik jari pada waktu masuk dan pulang kantor namun masih ada pegawai yang melanggar ketentuan tersebut. Dalam hal ini kepada pegawai yang melanggar peraturan disiplin diberikan sanksi teguran lisan dan tertulis.Pembinaan disiplin ini terus dilakukan agar tidak ada lagi pegawai yang melanggar ketentuan disiplin

\section{Pembinaan Pendidikan dan Latihan}

Pendidikan dan latihan dimaksudkan sebagai suatu cara untuk meningkatkan kemampuan/kecakapan pegawai dan untuk menyiapkan tenaga yang cakap untuk menduduki suatu jabatan. Undang-Undang Nomor 43 Tahun 1999 pasal 31 menyatakan, untuk mencapai daya guna dan hasil guna yang sebesar besarnya diadakan pengaturan dan penyelenggaraan pendidikan dan latihan jabatan pegawai Negeri Sipil yang bertujuan untuk meningkatkan pengabdian, mutu, keahlian, kemampuan dan ketrampilan menciptakan adanya pola pola berpikir yang sama, menciptakan dan mengembangkan metode kerja yang lebih baik, serta membina karier Pegawai Negeri Sipil. Dinas pendidikan Kabupaten Pidie telah melakukan pembinaan pegawai melalui Pendidikan dan Latihan terhadap sejumlah pegawai untuk dapat menduduki suatu jabatan tertentu dengan berbagai jenjang pendidikan dan latihan baik yang diselenggarakan di Kabupaten Pidie maupun di luar Kabupaten Pidie.

\section{Pembinaan Kesejahteraan.}

Untuk dapat mendorong Pegawai Negeri Sipil memusatkan perhatian sepenuhnya dalam melaksanakan tugas perlu diusahakan dan ditingkatkan kesejahteraan material dan spiritual seperti jaminan hari tua, bantuan perawatan kesehatan, bantuan kematian, ceramah keagamaan dan lain-lain Sistem pembinaan karier Pegawai Negeri Sipil harus disusun sedemikian rupa sehingga menjamin terciptanya kondisi objektif yang dapat mendorong peningkatan motivasi dan prestasi pegawai Dalam hal pembinaan kesejahteraan pegawai Dinas pendidikan Kabupaten Pidie telah 
melaksanakan pembinaan tersebut sesuai dengan ketentuan yang berlaku, karena dengan adanya kesejahteraan yang dirasakan oleh pegawai, motivasi kerja dan loyalitas pegawai terhadap pekerjaan akan lebih meningkat.

\section{Tupoksi}

Tugas pokok dan fungsi (Tupoksi) pada sebuah organisasi diatur berdasarkan suatu peraturan baik dari Pemerintah Daerah/Qanun maupun dari Pemerintah Atasan. Tupoksi merupakan suatu bentuk tugas dan fungsi dari setiap organisasi, dengan adanya tupoksi yang jelas dalam sebuah organisasi, maka semua tugas dan tanggung jawab dari masing-masing bidang dapat terlaksana sesuai dengan peraturan perundang-undangan yang berlaku.

Tupoksi Dinas pendidikan Kabupaten Pidie diatur berdasarkan Qanun Kabupaten Pidie Nomor 4 Tahun 2013 tentang Perubahan atas Qanun kabupaten Pidie Nomor 4 Tahun 2008 tentang Susunan Organisasi dan Tata Kerja Dinas daerah Kabupaten Pidie, dengan adanya Tupoksi yang jelas setiap pegawai dapat menjalankan tugasnya sebagaimana yang diatur dalam peraturan yang berlaku, dan setiap tugas yang dijalankan oleh pegawai tidak boleh keluar dari tupoksi yang ada. Kejelasan Tupoksi dapat mendorong pegawai lebih termotivasi dalam menjalankan tugasnya apalagi tugas-tugas yang dilaksanakan didukung oleh sarana dan prasarana yang lengkap, sehingga hasil pekerjaan yang diperoleh lebih efektif dan efisien serta tepat sasaran.

\section{Sumber Daya Manusia}

Sumber Daya Manusia adalah orangorang yang bekerja pada suatu organisasi baik organisasi Pemerintah maupun swasta. Manajemen Sumber daya Manusia yang baik ditujukan kepada peningkatan kontribusi yang dapat diberikan oleh para pekerja dalam organisasi kearah tercapainya tujuan organisasi. Terbentuknya satuan organisasi yang mengelola sumber daya manusia dimaksudkan bukan sebagai tujuan, akan tetapi sebagai alat untuk meningkatkan efisiensi, efektivitas dan produktivitas kerja organisasi secara keseluruhan.

Struktur sebuah organisasi menggambarkan dua jenis kegiatan yaitu kegiatan pokok dan kegiatan penunjang. Yang dimaksud kegiatan pokok adalah adalah seluruh usaha yang dilakukan berkaitan langsung dengan tujuan dan sasaran yang ingin di capai oleh organisasi yang bersangkutan. Sedangkan kegiatan penunjang adalah keseluruhan upaya yang dibuat oleh satuan-satuan kerja tertentu yang meskipun tidak terlibat langsung dalam usaha pencapaian tujuan dan berbagai sasaran organisasi tetapi memberikan dukungan kuat ke arah keberhasilan penyelenggaraan tugas pokok Keberadaan sumber daya manusia pada Dinas pendidikan Kabupaten Pidie adalah untuk mencapai tujuan Dinas yang didasarkan kepada tupoksi yang telah ditetapkan dalam peraturan perundang-undangan yang berlaku.. Untuk mencapai tujuan tersebut diperlukan Sumber daya Manusia yang profesional dengan penuh rasa tanggung jawab dalam menjalankan tugas dan fungsinya. Oleh karena itu diperlukan berbagai pembinaan terhadap sumber daya manusia agar tercapai tujuan dimaksud.

Dengan adanya sumber daya manusia sebagaimana krieria yang telah disebutkan di atas, Dinas pendidikan Kabupaten Pidie telah menjalankan sebagian tugas dari Pemerintah Daerah dalam bidang pendidikan.

\section{Peraturan Perundang-undangan}

Pelaksanaan Peraturan Perundang-
undangan telah digariskan pengangkatan
pegawai dalam jabatan harus di dasarkan pada sistem prestasi kerja (merit system),artinya pengangkatan berdasarkan kecakapan, bakat, pengalaman, dan kesehatan sesuai dengan kriteria yang telah digariskan. Ternyata dalam implementasinya sebagai akibat bias dalam pola rekruitmen, lebih menampakkan sistem kawan (patronage system), yaitu pengangkatan pegawai didasarkan atas adanya hubungan subyektif, yaitu hubungan yang diperhitungkan antara subyek-subyeknya. Dalam sistem ini pada dasarnya terdapat beberapa hubungan subyektif antara lain:

a. Hubungan yang bersifat politik (spoil System)

b. Hubungan yang non politik (nepotism).

Juga mengandung unsur nepotism (penerimaan pegawai yang didasarkan pada hubungan darah, maupun kawan), yang dapat mengakibatkan telah diangkatnya orang-orang yang tidak cakap, tertutupnya kemungkinan kesempatan bagi orang biasa/penduduk untuk melamar suatu jabatan, sering timbul adanya rasa tidak puas dari para pegawai yang ada dalam organisasi yang bersangkutan karena tidak mendapat perlakuan secara adil. Disamping itu pengangkatan jabatan struktural mengandung unsure spoil system (penerimaan 
pegawai yang dasarnya adalah pertimbangan politis untuk memberikan dukungan terutama pada partai yang berkuasa). Yang artinya jabatan-jabatan yang penting dan strategis hampir seluruhnya diduduki oleh anggota partai politik yang menang dalam pemilihan umum, dan para pemegang jabatan dari partai politik yang kalah maka ia harus segera berhenti untuk mengundurkan diri dari jabatannya masingmasing.

Pengangkatan jabatan stuktural dengan merit system sangat efektif dimana kesempatan bekerja selalu terbuka untuk umum, dapat diperoleh tenaga-tenaga yang cakap, dan dapat mendorong calon-calon pegawai yang belum memenuhi syarat untuk membenahi diri lebih menigkatkan profesionalismenya dalam tugas dan kewajiban sebagai Pegawai NegeriSipil.

Pembuatan peraturan perundangundangan pada sebuah organisasi mutlah diperlukan, karena dengan adanya suatu peraturan apapun aktivitas yang dilakukan oleh organisasi tersebut tidak boleh menyimpang dari peraturan yang ada. Tanpa adanya suatu peraturan yang jelas tidak mungkin suatu organisasi akan sukses dalam mencapai visi dan misinya kearah yang lebih memuaskan. Dengan adanya peraturan yang jelas setiap pegawai akan lebih mudah dalam menjalankan tupoksinya.

Keberadaan peraturan pada sebuah organisasi merupakan salah satu faktor pendorong bagi setiap pegawai, karena setiap pegawai telah dibebankan dengan masing-masing tugas dan tanggung jawab, namun demikian dengan adanya peraturan tersebut tugas dan tanggung jawab pegawai hanya dibatasi dalam ruang lingkup tupoksinya masing-masing

Dinas pendidikan Kabupaten Pidie telah menetapkan peraturan dinas dalam bentuk Qanun yang dibuat oleh Pemerintah daerah Kabupaten Pidie, semua tugas dan tanggung jawab masing-masing bidang telah diatur dalan Qanun tersebut, sehingga pegawai lebih mudah dalam melaksanakan tugasnya dan tidak terjadi tumpang tindih dalam menjalan tugas.

\section{Faktor Penghambat}

\section{Persyaratan Kenaikan Pangkat}

Kenaikan pangkat bagi seorang Pegawai Negeri Sipil diatur dalam Peraturan Pemerintah Nomor 12 Tahun 2002 tentang Perubahan Atas Peraturan pemerintah Nomor 99 Tahun 2000 tentang Kenaikan Pangkat Pegawai Negeri Sipil, berdasarkan Peraturan Pemerintah tersebut kenaikan pangkat pegawai dibagi dua sistem yaitu sistem kenaikan pangkat reguler dan sistem kenaikan pangkat pilihan periode kenaikan pangkat Pegawai Negeri Sipil ditetapkan pada tanggal 1 April dan 1 Oktober setiap tahunnya. Kenaikan pangkat pertama sekali sebagaimana yang telah disebutkan diatas maka Pegawai Negeri Sipil dihitung sejak pengangkatan sebagai Calon Pegawai Negeri Sipil. Kenaikan pangkat reguler bagi seoarang Pegawai Negeri Sipil diberikan kepada Pegawai Negeri Sipil yang:

a. Melaksanakan tugas belajar sebelumnya tidak menduduki jabatan struktural atau jabatan fungsional tertentu,

b. Diperkerjakan atau diperbantukan secara penuh diluar intansi induk, tidak menduduki jabatan struktural atau jabatan fungsional tertentu.

Kenaikan pangkat reguler diberikan setingkat lebih tinggi apabila :

a. Sekurang-kurangnya empat tahun dalam pangkat terakhir.

b. Setiap tahun penilaian prestasi kerja sekurang-kurangnya bernilai baik dalam dua tahun terakhir.

Kenaikan Pangkat pilihan diberikan kepada Pegawai Negeri Sipil yang menduduki jabatan struktural dan pangkatnya masih satu tingkat di bawah jenjang pangkat terendah yang ditentukan untuk jabatan itu, dapat dinaikkan pangkatnya setingkat lebih tinggi apabila :

a. Telah satu tahun dalam pangkat yang dimilikinya

b. Sekurang-kurangnya didudukinya

c. Setiap unsur penulaian prestasi kerja sekurang-kurangnya bernilai baik dalam dua tahun terakhir

Mengingat persyaratan kenaikan pangkat yang begitu komplit, kadang kala menjadi penghambat bagi Pegawai negeri Sipil Dinas pendidikan Kabupaten Pidie dalam pengurusan kenaikan pangkat Dilihat dari kenyataan yang ada terdapat sejumlah pegawai yang tertunda kenaikan pangkat, ada pegawai yang harus menunggu sampai dengan empat belas tahun untuk proses kenaikan pangkat karena terkendala dengan latar belakang pendidikan yang tidak mendukung untuk kenaikan pangkatnya, ada yang sembilan tahun dan ada yang tujuh tahun masa tunggu untuk dapat diproses kenaikan pangkat.

\section{Jenis kenaikan Pangkat}

Ada beberapa sistem kenaikan pangkat Pegawai Negeri Sipil, akan tetapi dalam 
penelitian ini yang dikaji adalah kenaikan pangkat reguler dan kenaikan pangkat pilihan.Sebagaimana yang telah dikemukakan sebelumnya Dinas pendidikan Kabupaten pidie telah memproses kedua sistem kenaikan pangkat tersebut, baik reguler maupun pilihan. Sistem kenaikan pangkat reguler semestinya dapat diberikan kepada semua pegawai yang tidak menduduki jabatan struktural, namun demikian kenaikan pangkat tersebut tidak semuanya dapat diproses tepat waktu, karena terkendala dengan berbagai alasan seperti latar belakang pendidikan, disiplin dan faktor lain. Sedangkan kenaikan pangkat pilihan telah diproses bagi pegawai yang menduduki jabatan struktural, namun demikian proses kenaikan pangkat pilihan tidak semudah yang dibayangkan karena Kepala Dinas pendidikan Kabupaten Pidie masih dalam pangkat IV/a, sementara ada pegawai yang sudah berpangkat IV/c dan IV/b. Sebelum Kepala Dinas pendidikan diangkat menjadi kepala Dinas beliau menjabat sebagai Pejabat Kepala Dinas (Pj).

\section{Dukungan Masyarakat}

Dalam bidang apapun sebuah organisasi bergerak dalam arti yang sebenar-benarnya ia menghasilkan suatu produk atau jasa bagi kelompok-kelompok tertentu di masyarakat, artinya produk tersebut baik barupa barang atau jasa harus diintegrasikan dalam arti luas yaitu dalam arti barang atau jasa yang hanya dihasilkan oleh organisasi-organisasi yang bergerak dibidang keniagaan saja. Dengan interpretasi yang demikian jelas terlihat bahwa tidak ada satupun organisasi yang dapat mempertahankan eksistensinya dan melestarikan keberadaannya tanpa mengkaitkan tujuan tujuan organisasi dengan masyarakat luas. Tidak ada satupun organisasi yang bisa mempertahankan dan melanjutkan eksistensinya dalam keadaan terisolir dan tanpa konteks. Berarti manajemen setiap organisasi harus memeiliki kepekaan terhadap tuntutan sosial yang ditujukan kepada organisasi yang bersangkutan. Dengan perkataan lain setiap organisasi mempunyai kewajiban sosial yang harus dipenuhi.

Bentuk nyata dari kegagalan sebuah organisasi mengkaitkan pencapaian tujuannya dengan pencap[aian tujuan masyarakat luas terlihat dalam dua wujud. Pertama, ialah bahwa masyarakat akan kehilangan kepercayaan terhadap organisasi yang bersangkutan. Kedua, sebagai akibat hilangnya kepercayaan tersebut masyarakat tidak lagi memberikan dukungannya kepada kebijaksanaan dan kegiatan organisasi tersebut. Jika suatu organisasi sudah kehilangan kepercayaan dan dukungan masyarakat, jelas bahwa cepat atau lambat, kehancuranlah yang merupakan akibatnya. Dinas Pendidikan Kabupaten Pidie merupakan sebuah organisasi yang tidak terlepas keberadaannya dari dukungan masyarakat, meskipun dinas tersebut merupakan organisasi pemerintah namun demikian dukungan masyarakat juga diperlukan untuk eksistensinya. Keberadaan Pegawai bila dikaitkan dengan masyarakat misalnya masyarakat menghendaki adanya pegawai dilingkungannya nanti apabila ada kegiatankeghiatan tertentu yang dilaksanakan di tengahtengah masyarakat seorang pegawai dapat memberi dukungan baik moril maupun materil untuk kegiatan tersebut. Berdasarkan hal tersebut kebaradaan pegawai ditengah-tengah masyarakat merupakan faktor pendukung terhadap jalannya aktifitas masyarakat.

\section{Peraturan Perundang-Undangan}

Setiap daerah berhak mengatur dan mengurus urusan rumah tangganya sendiri sesuai dengan peraturan perundang-undangan yang berlaku. Peraturan perundang-undangan baik yang di buat oleh Pemerintah daerah ataupun Pemerintah Pusat selalu berubah-ubah hal ini dikarenakan terjadinya perubahanperubahan dalam bentuk organisasi seperti perampingan organisasi faktor lingkungan dan lain-lain. Setiap terjadinya perubahan undangundang atau peraturan akan selalu berimbas pada susunan organisasi, tupoksi dan hal-hal lain yang timbul akibat dari perubahan peraturan tersebut dan ini merupakan suatu hambatan bagi pegawai dalam menjalankan tugasnya. Apalagi perubahan peraturan disertai dengan mutasi jabatan, pasti akan terjadi masalah dalam organisasi tersebut, karena pegawai harus mulai bekerja pada jabatan yang baru dengan peraturan yang baru pula.

Dinas pendidikan Kabupaten Pidie sudah beberapa kali terjadi perubahan peraturan, dengan sendirinya tupoksinya juga berubah. Perubahan tersebut menjadi faktor penghambat bagi pegawai dalam pengurusan pangkat dan jabatan. Misalnya seorang pegawai sedang diproses kenaikan pangkat oleh pegawai lama yang bertugas dibidang kepangkatan tiba-tiba terjadi perubahan peraturan dengan sendirinya proses tersebut terhenti. Sementara yang duduk di bagian kepangkatan pegawai sudah digantikan dengan pegawai baru, dengan 
sendirinya proses kenaikan pangkat akan tertunda karena pegawai baru dibidang kepangkatan harus mempelajari dulu aturanaturan tentang kepangkatan pegawai.

\section{Kesimpulan.}

Berdasarkan pembahasan yang telah diuraikan pada bab-bab sebelumnya, di sini dapat diambil beberapa kesimpul berkenaan dengan Pembinaan Pegawai Negeri Sipil pada Dinas pendidikan Kabupaten Pidie sebagaimana Implimentasi Peraturan Pemerintah Nomor 12 Tahun 2002 tentang Kenaikan Pangkat Pegawai Negeri Sipil terkait dengan kenaikan pangkat berdasarkan sistem karier dan sistem prestasi kerja antara lain :

1. Pegawai Negeri Sipil merupakan unsur aparatur negara yang menjalankan tugas Pemerintahan dan pembangunan dalam upaya mencapai tujuan pembangunan Nasional secara menyeluruh sebagaimana dimaksudkan dalam Pembukaan UndangUndang Dasar 1945, adalah melindungi segenap Bangsa Indonesia dan seluruh tumpah darah Indonesia serta untuk memajukan kesejahteraan kehidupan bangsa serta ikut melaksanakan ketertiban dunia yang berdasarkan kemerdekaan, perdamai abadi dan keadilan sosial bagi seluruh rakyat Indonesia Untuk mencapai tujuan Nasional sebagaimana dimaksudkan diatas maka diperlukan adanya Pegawai Negeri Sipil yang berdedikasi tinggi dan penuh kesetiaan serta ketaatan kepada Pancasila, UndangUndang Dasar 1945, Negara dan Pemerintah serta bersatu padu, bermental baik, berwibawa, berdaya guna dan berhasil guna, bersih dan berkualitas tinggi dan sadar terhadap tanggung jawab sebagai unsur Aparatur Negara.

2. Dalam upaya mewujudkan Pegawai Negeri Sipil tersebut bagi Dinas Pendidikan Kabupaten Pidie perlu melakukan langkah-langkah pembinaan dan pendidikan yang sesuai dengan sistem karier dan sistem prestasi kerja. Pembinaan yang dilakukan didasarkan kapada pasal 12 ayat (1) Undang-Undang Nomor 43 Tahun 1999 tentang perubahan atas Undang-Undang Nomor 8 Tahun 1974 tentang pokok-pokok kepegawaian yang berbunyi "Manajemen Pegawai Negeri Sipil diarahkan untuk menjamin penyelenggaraan tugas Pemerintahan dan pembangunan. Dengan dilandasi pada uraian diatas, maka dapat dikatakan bahwa Pegawai Negeri Sipil merupakan sesuatu hal yang perlu dibina secara terus menerus dan kontinue, sejak mulai dari rekrutmen, pengangkatan menjadi Pegawai sampai Pegawai yang bersangkutan dipensiunkan, oleh karena itu dengan tujuan untuk menjamin penyelenggaraan tugas dalam bidang Pemerintahan dan pembangunan secara berdaya guna dan berhasil guna dan mampu menjalankan tugas-tugas yang telah dibebankan kepadanya.Pegawai Negeri Sipil dapat benar-benar mematuhi semua ketentuan atau Peraturan Perundang-Undangan yang berlaku serta penuh rasa tanggung jawab terhadap pelaksanaan tugas. Dalam suatu organisasi banyak hal memerlukan pengelolaan yang profesional dan terpisah dari hal-hal lain. Kita mengenal berbagai jenis manajemen dalam organisasi, misalnya manajemen produksi, manajemen pemasaran, manajemen keuangan, manajemen informasi, dan tentunya manajemen Sumber Daya Manusia. Jadi mana yang paling penting dari semua jenis manajemen ini? Jawabannya semua mempunyai derajat kepentingan yang sama dalam hal kontribusi terhadap pencapaian tujuan organisasi.

3. Pangkat adalah kedudukan yang menunjukkan tingkat seorang pegawai negeri dalam rangkaian susuan kepegawaian dan digunakan sebagai dasar penggajian. Setiap pegawai Negeri Sipil yang telah memenuhi syarat-syarat yang ditentukan dapat diberikan kenaikan pangkat.. Kenaikan pangkat adalah penghargaan yang diberikan atas pengabdian Pegawai Negeri Sipil yang bersangkutan terhadap negara. Di samping itu kenaikan pangkat juga merupakan dorongan kepada Pegawai Negeri Sipil untuk lebih meningkatkan pengabdian.

4. Kenaikan pangkat pegawai Negeri Sipil Dinas pendidikan Kabupaten Pidie berdasarkan sistem karier dan sistem prestasi kerja belum sepenuhnya efektif dilaksanakan dimana ada sebagian pegawai tidak dapat diproses kenaikan pangkat karena terkendala dengan 
berbagai alasan seperti faktor pendidikan dan faktor lain sehingga kenaikan pangkat regular tidak dapat diproses tepat waktu. Sedangkan kenaikan pangkat pilihan dapat diberikan kepada pegawai yang menduduki jabatan struktural, ada yang baru setahun duduk dalam jabatan struktural sudah diproses kenaikan pangkat.

5. Dinas Pendidikan Kabupaten Pidie merupakan salah satu Dinas daerah yang dipimpin oleh seorang Kepala Dinas yang tunduk dan bertanggung jawab kepada Bupati melalui Sekretaris Daerah. Dinas Pendidikan Kabupaten Pidie pembentukanya di dasarkan kepada Qanun Kabupaten Pidie Nomor 4 Tahun 2013 tentang Perubahan Kedua Atas Qanun Kabupaten Pidie Nomor 4 Tahun 2008 tentang Susunan Organisasi dan tata Kerja Dinas Daerah Kabupaten Pidie.

\section{Saran-Saran}

1. Perlu ditinjau kembali mengenai mekanisme pengaturan sistem kenaikan pangkat regular bagi pegawai yang tidak menduduki jabatan strukturan agar tidak ada pegawai yang harus menunggu waktu yang cukup lama untuk dapat diproses kenaikan pangkatnya.

2. Bagi pegawai yang akan diproses kenaikan pangkat baik kenaikan pangkat pilihan maupun kenaikan pangkat regular dapat diproses sesuai dengan ketentuan yang berlaku begitu pula dengan kenaikan pangkat penyimpangan.

\section{DAFTAR KEPUSTAKAAN}

\section{Buku}

Ec.Alex S.Nitisemito. (2005) Manajemen Personalia. Jakarta : Gunung Agung

Miles dan Huberman. (2010). Analisis Data Kualitatif. Jakarta: Universitas Indonesia (UI-Press)

Manullang. (2005) Dasar-Dasar Manajemen. Jakarta: Ghalia Indonesia.

(2002). Pengembangan Kepegawaian. Jakarta: Ghalia Indonesia.

Moekijat. (2007). Manajemen Kepegawaian. Bandung: Alumni.
Moleong, Lexy J. (2014). Metode Penelitian Kualitatif. Bandung: Remaja Rosdakarya

Muhammad, Syuhadhak. (2007). Manajemen Sumber Daya Manusia Teori dan Praktek Dilingkungan Pegawai Negeri Sipil. Jakarta: STIA LAN Press.

Prasetyo, Irawan. dkk. (2010). Manajemen Sumber Daya manusia. Jakarta: STIA LAN Press.

Riyadi, Soeprapto dan Irawan, Noer. (2011). Manajemen Personalia. Malang: FIA, UNIBRAW.

Sutopo. (2006). Metodelogi Penelitian. Jakarta: Bina Aksara

Siagian, SP. (2006). Administrasi Kepegawaian. Jakarta: Ghalia Indonesia

Soetandyo. (2010). Metode Penelitian Ilmiah, Jakarta: Bina Aksara

Thoha, Miftah. (2008) Aspek-Aspek Pokok Ilmu Administrasi. Jakarta Ghalia Indonesia.

Handoko, T. Hani, (2005) Manajemen Personalia dan Sumber Daya Manusia. Yogyakarta: Liberty.

Wijaya, AW. (2012). Administrasi Kepegawaian. Jakarta: CV. Rajawali.

B. Dokumen

Undang-Undang Nomor 43 Tahun 1999 tentang Perubahan Atas UU No.8 Tahun 1974 tentang Pokok-Pokok Kepegawaian, Jakarta.

Undang-Undang Republik Indonesia Nomor 5 Tahun 2014 tentang Aparatur Sipil Negara, Jakarta

Peraturan Pemerintah RI No 12 Tahun 2002 tentang Perubahan Atas Peraturan Pemerintah Nomor 99 Tahun 2000 tentang Kenaikan Pangkat Pegawai Negeri Sipil, Citra Umbara, Bandung.

Peraturan Pemerintah RI No 13 Tahun 2002 tentang Perubahan Peraturan Pemerintah Nomor 100 Tahun 2000 tentang Pengangkatan Pegawai Negeri Sipil 
Dalam Jabatan Struktural, Citra Umbara, Bandung.

Peraturan Pemerintah No.53 Tahun 2007 tentang Peraturan Disiplin PNS, Jakarta.
Qanun Kabupaten Pidie Nomor 4 Tahun 2013

Tentang Perubahan Atas Qanun Kabupaten Pidie Nomor 4 Tahun 2008 tentang Susunan Organisasi dan tata Kerja Dinas pendidikan Kabupaten Pidie Sigli 